\title{
Syn-exhumation melting of the subducted continental crust: Geochemical evidence from Early Paleozoic granites in North Qaidam, northern Tibet
}

\author{
GUO-CHAO SUN*, PENG GAO, ZI-FU ZHAO
}

CAS Key Laboratory of Crust-Mantle Materials and Environments, University of Science and Technology of China, Hefei 230026, China (sgc@mail.ustc.edu.cn)

\footnotetext{
Syn-exhumation partial melting of the deeply subducted continental crust is common in collisional orogens, and the resulted felsic melts may modify the composition of the mantle wedge above continental subduction zones. To investigate the process of crustal anatexis and its significance on crust-mantle interaction during continental collision, a combined study of whole-rock major-trace elements and $\mathrm{Sr}-\mathrm{Nd}-\mathrm{Hf}$ isotopes as well as zircon $\mathrm{U}-\mathrm{Pb}$ ages and $\mathrm{Lu}-\mathrm{Hf}$ isotopes was performed for Early Paleozoic granites from North Qaidam, a collisional orogen that contains ultrahigh-pressure (UHP) metamorphic rocks in northern Tibet. The results indicate that the deeply subducted continental crust underwent high degree of partial melting during the collisional orogeny, giving rise to the target granites. Zircon $\mathrm{U}-\mathrm{Pb}$ dating yielded ages of $416 \pm 6 \mathrm{Ma}$ to $393 \pm 2 \mathrm{Ma}$ for granitic magmatism, which postdates the UHP metamorphism but is coeval with exhumation event of the deeply subducted continental crust. Thus, the studied granites are the product of syn-exhumation magmatism during the continental collision. Relict zircons show concordant Neoproterozoic and Early Paleozoic U-Pb ages, respectively, consistent with the protolith and metamorphic ages of UHP meta-igneous rocks in the orogen. The granites are calcalkaline to high-K calc-alkaline and metaluminous to weakly peraluminous, with arc-like trace element distribution patterns. They exhibit enriched whole-rock $\mathrm{Sr}-\mathrm{Nd}$ isotope compositions with high $\left({ }^{87} \mathrm{Sr} /{ }^{86} \mathrm{Sr}\right)_{i}$ ratios of $0.7058-0.7195$ but negative $\varepsilon_{\mathrm{Nd}}(\mathrm{t})$ values of -7.1 to -1.4 . Their $\varepsilon_{\mathrm{Hf}}(\mathrm{t})$ values range from -2.8 to 2.7 for whole-rock and from -8.6 to 4.7 for zircon. These geochemical features are generally comparable with those of the UHP metaigneous rocks in the orogen, suggesting a genetic link between them. Therefore, the granites were produced by partial melting of the deeply subducted continental crust during the decompressional exhumation. The granitic melts produced would not only contribute to the formation of syn-exhumation granitic intrusions but also serve as metasomatic agents for crust-mantle interaction in continental subduction channels.
} 